\title{
Glial fibrillary acidic protein is one of the key factors underlying neuron-like elongation in PC12 cells
}

\author{
MAKI SUGAYA-FUKASAWA*, TORU WATANABE* , MICHIKO TAMURA, \\ SATSUKI EGASHIRA and HISASHI HISATOMI
}

\begin{abstract}
Laboratory of Cellular and Molecular Biochemistry, Department of Materials and Life Science, Seikei Universty, Musashino-shi, Tokyo 180-8633, Japan
\end{abstract}

Received August 27, 2010; Accepted November 1, 2010

DOI: $10.3892 /$ etm.2010.162

\begin{abstract}
Nerve growth factor (NGF) normally induces the differentiation of PC12 cells into a neuron-like phenotype. In this study, we found that exposure of PC12 cells to a temperature of $42^{\circ} \mathrm{C}$ for $24 \mathrm{~h}$ significantly decreased NGF-induced neurite elongation. Glial fibrillary acidic protein (GFAP) levels were decreased when PC12 cells were exposed to the heat stress, while PC12 cells overexpressing the gene encoding GFAP showed resistance. Mock-transfected PC12 cells exposed to NGF could be cultured for $72 \mathrm{~h}$ at $37^{\circ} \mathrm{C}$, whereas GFAP-transfected PC12 cells exposed to NGF could be cultured for over $100 \mathrm{~h}$. Our results suggest that GFAP is necessary for the long-term maintenance of cells with a neuron-like phenotype.
\end{abstract}

\section{Introduction}

Glial fibrillary acidic protein (GFAP) is expressed in astrocytes in the central nervous system (CNS) (1) and is involved in many cellular functioning processes, such as cell structure and movement, cell communication and the functioning of the blood-brain barrier $(2,3)$. It was found that the levels of several proteins expressed in astrocytes are altered in an Alzheimer's disease model (4,5), and cleavage of GFAP may contribute to astrocyte injury and damage in the Alzheimer's disease brain (6-8). GFAP plays an important role in mitosis, directly or indirectly, by adjusting the filament network present in the cell. During mitosis, the amount of phosphorylated GFAP increases and moves to the cleavage furrow (9). In vitro, astrocytes treated with antisense RNA against GFAP do not

Correspondence to: Professor Hisashi Hisatomi, Laboratory of Cellular and Molecular Biochemistry, Department of Materials and Life Science, Seikei Universty, 3-3-1 Kichijoji, Kita-machi, Musashino-shi, Tokyo 180-8633, Japan

E-mail: hisatomi@st.seikei.ac.jp

${ }^{*}$ Contributed equally

Key words: anti-apoptosis, nerve growth factor, astrocyte form a neuron-like phenotype (10). There are multiple disorders associated with inactive GFAP regulation, and mutations in the coding region of the GFAP gene are associated with Alzheimer's disease (11). Therefore, GFAP is thought to play crucial roles in the development and differentiation of astrocytes and is believed to be involved in the long-term maintainance of normal CNS myelination (12). However, the mechanisms by which GFAP is involved in the development and differentiation of astrocytes are not yet completely understood. To better understand the effect of GFAP expression on neurons, we generated stable PC12 cell lines overexpressing this gene.

The PC12 cell line, which was derived from a pheochromocytoma of the rat adrenal medulla (13), is the most common cell line used as neuron-like cells with neuron-like elongation abilities. Maintenance of the neuronal phenotype and survival of differentiated PC12 cells under serum-free conditions require constant nerve growth factor (NGF) exposure. PC12 cells stop dividing and terminally differentiate when treated with NGF. In the present study, PC12 cells with neuron-like elongation underwent apoptosis within 70-80 h. However, the PC12 cells overexpressing pGFAP from the plasmid underwent cell death $120 \mathrm{~h}$ after NGF exposure. The overexpression of GFAP delayed cell death in the PC12 cells.

\section{Materials and methods}

Cell culture. The PC12 cell line was purchased from the Japan Health Science Foundation (HSRRB, Osaka, Japan) and maintained in DMEM supplemented with heat-inactivated fetal bovine serum and horse serum. After culture for $48 \mathrm{~h}$, the cells were treated with $1.0 \mu \mathrm{M}$ NGF (Kyowa, Tokyo, Japan) for $0,24,48,72,96$ or $120 \mathrm{~h}$. All cells were grown in $5 \% \mathrm{CO}_{2}$ at $37^{\circ} \mathrm{C}$. The temperature was adjusted to $42^{\circ} \mathrm{C}$, and cells were observed. Apoptosis was detected by Annexin $\mathrm{V}$ and propidium iodide (PI) staining using flow cytometry (Quanta SC, Beckman Coulter, Fullerton, CA, USA).

RT real-time PCR analysis. Total RNA was extracted from the PC12 cells using the QuickGene RNA Cultured Cell HC Kit S (Fujifilm, Kanagawa, Japan) following the manufacturer's instructions. The final RNA preparations were resuspended in diethylpyrocarbonate-treated water and quan- 


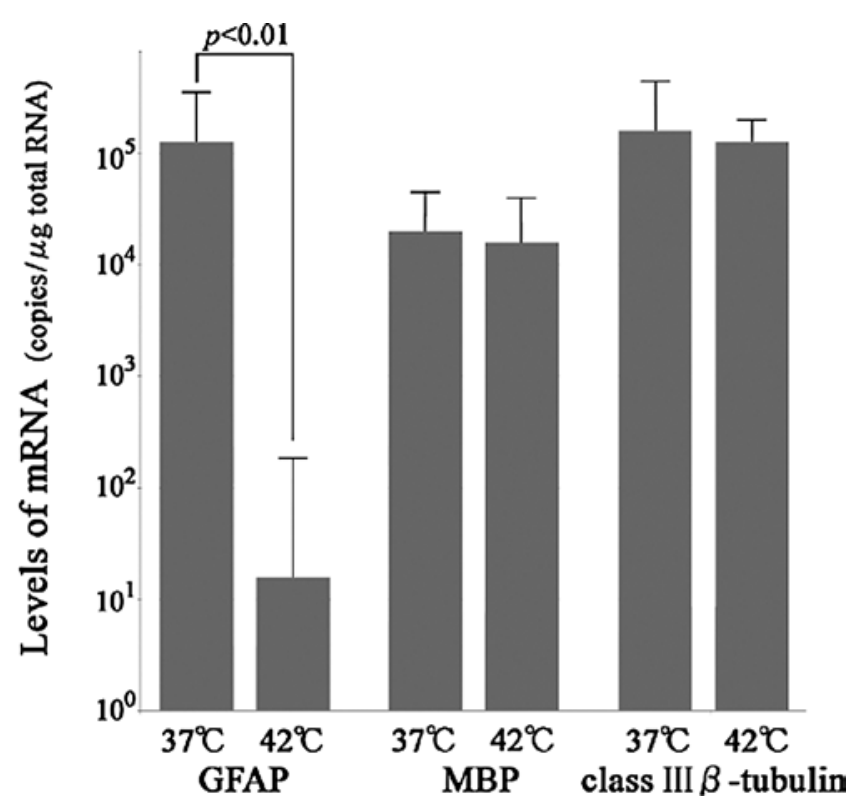

Figure 1. GFAP, MBP and class III $\beta$-tubulin mRNA in the PC12 cells exposed to NGF at 37 or $42^{\circ} \mathrm{C}$ for $24 \mathrm{~h}$. Triplicate RT real-time PCR analyses were performed as described in Materials and methods. As normalization to the GAPDH housekeeping gene is unreliable, mRNA expression levels are presented as the mRNA copy number per $\mu \mathrm{g}$ total RNA.

tified by absorbance analysis at $260 \mathrm{~nm}$. cDNA was prepared by incubating DNase-treated total RNA $(0.1 \mu \mathrm{g})$ with M-MLV reverse transcriptase (Invitrogen, Carlsbad, CA, USA) in the presence of random primers (Invitrogen). The real-time PCR reaction mixture was prepared using a FastStart SYBR Green Master (Roche Diagnostics, Mannheim, Germany). The primer set for amplification of a GFAP mRNA was designed according to GenBank NM_017009, using a forward primer at the exon 2 region, 5'-CAA GAT GAA ACC AAC CTG AGG CT-3', and a reverse primer at the exon 4 region, 5'-GGC TTG GCC ACA TCC ATC T-3' (product length 221 bp). The primer set for amplification of a myelin basic protein $(M B P)$ mRNA was designed according to GenBank M25889, using a forward primer at the exon 4-6 region, 5'-GGC AAG GAC TCA CAC ACR AGA ACT-3', and a reverse primer at the exon 7-8 region, 5'-GGG ACA GGC CTC TCC CCT T-3' (product length $154 \mathrm{bp}$ ). The primer set for amplification of a class III $\beta$-tubulin mRNA was designed according to GenBank AF459021, using a forward primer at the exon 2 region, 5'-ATA GAC CCC AGC GGC AAC TAT GTG-3', and a reverse primer at the exon 3 region, 5'-AGG CCT GAA TAG GTG TCC AAA GGC-3' (product length 174 bp). The real-time PCR reaction was carried out for 45 cycles $\left(95^{\circ} \mathrm{C}\right.$ for $20 \mathrm{sec}, 60^{\circ} \mathrm{C}$ for $30 \mathrm{sec}$ and $72^{\circ} \mathrm{C}$ for $20 \mathrm{sec}$ ) using an iCycler $\mathrm{iQ}^{\mathrm{TM}}$ Real-Time Detection System (Bio-Rad, Hercules, CA, USA). GAPDH cDNA was amplified for normalization (Applied Biosystems, Foster City, CA, USA); mRNA levels are presented as the mRNA copy number per $\mu \mathrm{g}$ total RNA.

Overexpression of $p G F A P$. The gene encoding GFAP was subcloned into the mammalian expression vector $\mathrm{pTriEX}^{\mathrm{TM}}-3$ (Merck, San Diego, CA, USA), and the entire sequence was verified by DNA sequencing. For overexpression in PC12 cells, GFAP was subcloned from $\mathrm{pTriEX}^{\mathrm{TM}}-3$ vectors into
A

$37^{\circ} \mathrm{C}$, mock

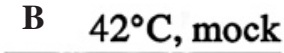

C $42^{\circ} \mathrm{C}$, pGFAP
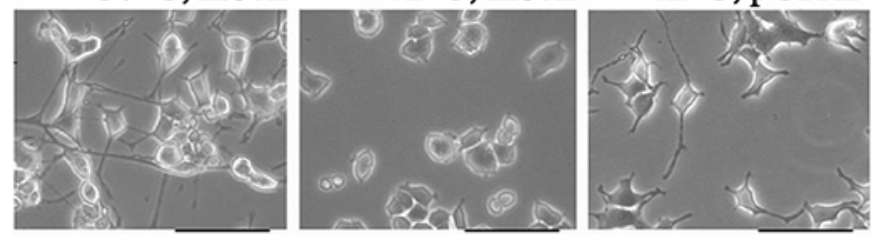

Figure 2. (A) Mock-transfected PC12 cells with NGF after $24 \mathrm{~h}$ in culture at $37^{\circ} \mathrm{C}$. (B) Mock-transfected cells with NGF after $24 \mathrm{~h}$ in culture at $42^{\circ} \mathrm{C}$. (C) pGFAP-transfected cells with NGF after $24 \mathrm{~h}$ in culture at $42^{\circ} \mathrm{C}$. The scale bar in each case represents $50 \mu \mathrm{m}$.
A

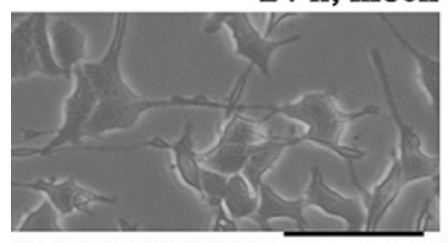

C

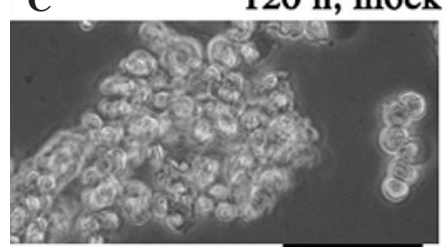

\section{B}

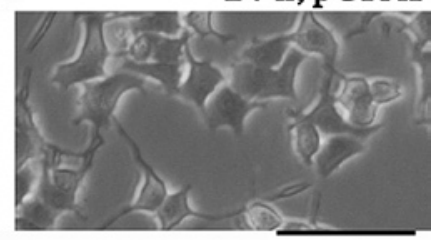

D

$120 \mathrm{~h}$, pGFAP

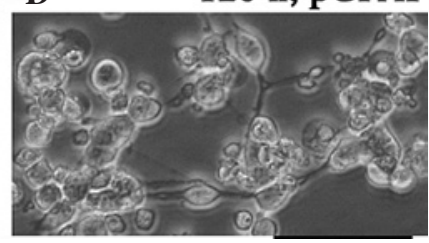

Figure 3. Determination of the transfection efficiency of pGFAP. (A) Mock-transfected $\mathrm{PC} 12$ cells with $\mathrm{NGF}$ in culture for $24 \mathrm{~h}$ at $37^{\circ} \mathrm{C}$. (B) pGFAP-transfected cells with NGF in culture for $24 \mathrm{~h}$ at $37^{\circ} \mathrm{C}$. (C) Mock-transfected cells with NGF in culture for $120 \mathrm{~h}$ at $37^{\circ} \mathrm{C}$. (D) pGFAPtransfected cells with NGF in culture for $120 \mathrm{~h}$ at $37^{\circ} \mathrm{C}$. The scale bar in each case represents $50 \mu \mathrm{m}$. Representative data from three independent experiments are shown.

NovaBlue Singles ${ }^{\mathrm{TM}}$ competent cells (Merck). The resultant plasmids were designated as pGFAP. Cells were seeded at a density of $10^{6}$ cells per $10-\mathrm{cm}$ dish and transfected with $8 \mu \mathrm{g}$ of plasmid DNA using $120 \mu 1$ of GeneJuice ${ }^{\circledR}$ Transfection reagent (Merck) for $2 \mathrm{~h}$ at $37^{\circ} \mathrm{C}$, after which time the DMEM medium plus $10 \%$ serum was changed. After $24 \mathrm{~h}$, cells were cultured under serum-free conditions and exposed to NGF stimulation. PC12 cells that were stably transfected with cDNAs encoding GFAP or the empty vector (mock) were grown to confluence in DMEM.

\section{Results}

RT real-time PCR. The levels of GFAP mRNA in the culture at $37^{\circ} \mathrm{C}$ ranged from $10^{4.6}$ to $10^{5.5}$ copies $/ \mu \mathrm{g}$ total RNA and were evaluated as the mean $\pm \mathrm{SE}\left(10^{5.1} \pm 10^{0.4}\right)$ copies $/ \mu \mathrm{g}$ total RNA. The levels of GFAP mRNA in the culture at $42^{\circ} \mathrm{C}$ ranged from 0.0 to $10^{2.1} \mathrm{copies} / \mu \mathrm{g}$ total RNA and were evaluated as the mean $\pm \mathrm{SE}\left(10^{1.2} \pm 10^{0.9}\right)$ copies $/ \mu \mathrm{g}$ total RNA; this difference was significant $(\mathrm{p}<0.01$; Student's $\mathrm{t}$-test). The levels of $M B P$ mRNA in the culture at 37 and $42^{\circ} \mathrm{C}$ were $10^{3.9}-10^{4.6}$ and $10^{3.8}$ $10^{4.6} \mathrm{copies} / \mu \mathrm{g}$ total RNA, respectively. The levels of class III $\beta$-tubulin mRNA in the culture at 37 and $42^{\circ} \mathrm{C}$ were $10^{4.7}-10^{5.6}$ and $10^{4.9}-10^{5.3}$ copies $/ \mu$ g total RNA, respectively (Fig. 1). 
Cell culture and overexpression of $p G F A P$. In the mocktransfected PC12 cells exposed to NGF, no apoptosis was induced at 0,24 or $48 \mathrm{~h}$ at $37^{\circ} \mathrm{C}$. After $72 \mathrm{~h}$, apoptosis was induced when the cell that expands the neurite was cultured at $37^{\circ} \mathrm{C}$ (data not shown). Exposure of $\mathrm{PC} 12$ cells to a temperature of $42^{\circ} \mathrm{C}$ for $24 \mathrm{~h}$ significantly decreased NGF-induced neuronlike elongation compared to cells cultured at $37^{\circ} \mathrm{C}$, while it was possible to maintain the neuron-like elongation at $42^{\circ} \mathrm{C}$ in the cells with pGFAP overexpression (Fig. 2). Mock-transfected PC12 cells showed similar features to control PC12 cells when incubated at $42^{\circ} \mathrm{C}$. In cells overexpressing pGFAP, neuron-like elongation was maintained in the culture for $120 \mathrm{~h}$ (Fig. 3).

\section{Discussion}

In the present study, GFAP was found to play an important role, directly or indirectly, in the protection of in vitro PC12 cultured cells from damage. Unfortunately, apoptosis progresses rapidly and the relation between the level of GFAP and the degree of inhibition of apoptosis is not yet understood. However, it appears that the existence of GFAP inhibited apoptosis in the PC12 cells with neuron-like elongation. Heat stress at a temperature of $42^{\circ} \mathrm{C}$ caused the PC12 cells to die. Neuron-like elongation was lost in the cultures at $42^{\circ} \mathrm{C}$, and these cells underwent apoptosis. Severe stress was found to play a role in the pathogenesis of neurodegenerative diseases, such as Alzheimer's disease. If neuronal cells can be made sufficiently resistant to stress, then the pathogenesis of neurodegenerative diseases should be slowed or decreased. Our results corroborate those of other researchers who have shown that GFAP is necessary for the long-term maintenance of the normal CNS (14-16).

The mechanism by which GFAP overexpression inhibits the apoptosis of PC12 cells is uncertain. However, we propose that this novel function of GFAP plays an important role in the ability of astrocytes to protect neuronal cells against apoptosis. These data support the concept that GFAP is responsible for many of the progressive astroglial changes that appear after CNS injury and disease. Further evaluation of this and other possible roles of GFAP, as well as the regulation of GFAP expression, are crucially important for the development of new strategies for maintaining homeostasis in the nervous system.

\section{References}

1. Rodríguez JJ, Olabarria M, Chvatal A and Verkhratsky A: Astroglia in dementia and Alzheimer's disease. Cell Death Differ 16: 378-385, 2009.

2. Bignami A, Eng LF, Dahl D and Uyeda CT: Localization of the glial fibrillary acidic protein in astrocytes by immunofluorescence. Brain Res 43: 429-435, 1972.

3. Antanitus DS, Choi BH and Lapham LW: Immunofluorescence staining of astrocytes in vitro using antiserum to glial fibrillary acidic protein. Brain Res 89: 363-367, 1975.

4. Counts SE and Mufson EJ: The role of nerve growth factor receptors in cholinergic basal forebrain degeneration in prodromal Alzheimer disease. J Neuropathol Exp Neurol 64: 263-272, 2005.

5. Angelopoulos P, Agouridaki H, Vaiopoulos H, et al: Cytokines in Alzheimer's disease and vascular dementia. Int J Neurosci 118: 1659-1672, 2008.

6. Eng LF and Ghirnikar RS: GFAP and astrogliosis. Brain Pathol 4: 229-237, 1994

7. Mouser PE, Head E, Ha KH and Rohn TT: Caspase-mediated cleavage of glial fibrillary acidic protein within degenerating astrocytes of the Alzheimer's disease brain. Am J Pathol 168: 936-946, 2006

8. Quinlan RA, Brenner M, Goldman JE and Messing A: GFAP and its role in Alexander disease. Exp Cell Res 313: 2077-2087, 2007.

9. Tardy M, Fages C, Le Prince G, Rolland B and Nunez J: Regulation of the glial fibrillary acidic protein (GFAP) and of its encoding mRNA in the developing brain and in cultured astrocytes. Adv Exp Med Biol 265: 41-52, 1990.

10. Lefrançois T, Fages C, Peschanski M and Tardy M: Neuritic outgrowth associated with astroglial phenotypic changes induced by antisense glial fibrillary acidic protein (GFAP) mRNA in injured neuron-astrocyte cocultures. J Neurosci 17: 4121-4128, 1997.

11. Brenner M, Johnson AB, Boespflug-Tanguy O, et al: Mutations in GFAP encoding glial fibrillary acidic protein are associated with Alexander disease. Nat Genet 27: 117-120, 2001.

12. Goss JR, Finch CE and Morgan DG: Age-related changes in glial fibrillary acidic protein mRNA in the mouse brain. Neurobiol Aging 12: 165-170, 1991.

13. Greene LA and Tischler AS: Establishment of a noradrenergic clonal line of rat adrenal pheochromocytoma cells which respond to nerve growth factor. Proc Natl Acad Sci USA 73: 2424-2428, 1976.

14. Pekny M, Levéen P, Pekna M, et al: Mice lacking glial fibrillary acidic protein display astrocytes devoid of intermediate filaments but develop and reproduce normally. EMBO J 14: 1590-1598, 1995.

15. Shibuki K, Gomi H, Chen L, et al: Deficient cerebellar long-term depression impaired eyeblink conditioning and normal motor coordination in GFAP mutant mice. Neuron 16: 587-599, 1996.

16. Liedtke W, Edelmann W, Bieri PL, et al: GFAP is necessary for the integrity of CNS white matter architecture and long-term maintenance of myelination. Neuron 17: 607-615, 1996. 